\title{
麺物性に及ぼす微生物起源トランスグルタミナーゼの影響
}

\author{
山㠃勝利 ${ }^{\S}$, 鳴戸 康, 丹野裕之*, 添田孝彦** \\ 味の素(株) 商品開発センター \\ *味の素(株) 大阪支社 加工グループ \\ **味の素(株) 食の文化センター
}

\section{Effects of Microbial Transglutaminase on Texture improvement of Chinese Noodles}

\author{
Katsutoshi Yamazaki ${ }^{\S}$, Yasushi Naruto, Hiroyuki Tanno* and Takahiko Soeda** \\ Ajinomoto., INC. Food Products Development Center, \\ 1-1, Suzuki-Cho, Kawasaki-Ku, Kawasaki-Shi, Kanagawa 210-8681 \\ * Ajinomoto., INC. OOSAKA branch office processing group, \\ 1-8-2, Nisitenmann, Oosaka-Shi, Oosakafu 530-0047 \\ ** Ajinomoto., INC. Foundation For Dietary Culture, \\ 1-16-7, Kyobasi, Cyuoku, Tokyo 104-8315
}

\begin{abstract}
We evaluated the effects of transglutaminase (MTG) treatment on the texture of Chinese noodles. When MTG was added to wheat flour at 1-10 units per gram of protein, the shear strength of boiled noodles increased with improvements in their resistance to bite. The mechanical properties of noodles were improved by the addition of both MTG and protein degradation products in combination compared with MTG alone. Moreover, when noodles were stored in a refrigerator after boiling, changes in the mechanical properties of noodles with time after boiling and loosening of the texture were also reduced by the addition of MTG. MTG also improved the anti-acid and anti-retort properties of noodles that should have a long shelf life. These improvements in the noodle texture were related to the quantity of G-L bond.
\end{abstract}

(Received May 22, 2003 ; Accepted Oct. 14, 2003)

近年，小麦粉や大豆などを原料とした麺類，パン，豆腐 などの農産加工品は国内のみならず, 海外にあっても健康 志向, ヘルシ一嗜好などの点から需要が拡大している。特 に，麺類は製缅加工技術，冷凍・乾燥技術などの向上によ り，冷涷麺や乾燥麺の市場む広がっている。

麺のおいしさは歯ごたえ，舌ざわり，喉越しなどで表現 されるように麺の粘弾性や表面の状態などの物理的性質が 影響している ${ }^{122}$.「ゆでうどん」は粘弾性で表現される「弾 力」と「粘り」のバランスのとれた「コシ」のある食感 ${ }^{344}$ が重視され, ゆで湎は歯ごたえの強い, 且つ, 長く惹込ん でも麺の形状の崩れもなく，茹でのびの抑制された麺質が 求められている. 特に, 中華湎は, 準強力粉の中であ厳選 された品質のものが使用されている. 食感的には, 強いコ シと，むちっとしたへテロ感のある麺物性が好ましいとさ れている.このように, 湎類は主原料の小麦粉の品質や製

テ210-8681 神奈川県川崎市川崎区鈴木町 1-1

* $\mathbf{T} 530-0047$ 大阪市北区西天満 1-8-2

** $\mathbf{T} 104-8315$ 東京都中央区京橋 1-16-7

$\S$ 連絡先 (Corresponding author), katsutoshi_yamazaki@ ajinomoto.com
麺条件など種々の製造要因との関連性 ${ }^{5 / 6)}$ やゆで麺，LL 麺 など麺の流通形態による兡物性の経時变化などによる品質 の劣化が課題となっている，劣化防止の為に，現状では卵 白や小麦グルテン, 増粘多糖類などの改質材を用いている が，本来の茹でたての麺のコシが保持されず，満足した品 質の屯のが得られていない，また，その品質を評価する為 に，Shimizu らは7)試作した装置によるクリープ測定を行 い，渡辺らは ${ }^{8)}$ フードレオメータによる応力緩和を測定し ているが，めんのレオロジー的性質についてはまだ十分明 らかになっていない。

これまで，タンパク質架橋重合化機能を持つ食品用䣲素 である微生物起源トランスグルタミナーゼ9)（以下，MTG と略す）を用いて麺物性の改質を検討してきた。 MTGは タンパク質中の Gln 残基と Lys 残基間の結合を形成させ る触媒となる酵素である。原料小麦粉中のグルテンに作用 して，小麦タンパク質の分子内および分子間に $\varepsilon$ - $(\gamma$-Glu $)$ Lys 架橋結合（以下， G-L 結合と略す）を形成する。この ような架橋重合化反応を利用して，新製品開発などの有用 な手段として種々の食品への利用技術開発を行ってき 
た ${ }^{10) 〜 12)}$. 特に, 小麦加工食品については小麦タンパク質の 網目構造を強化して麺物性の改質の有用性を見つけ出すこ とに成功したことから, 本報では中華湎類の麺食感の改質 を茹で麺，酸処理およびレトルト処理した LL 麺を中心に その物性に及ぼす MTGの効果について報告する.

\section{実 験 方 法}

\section{MTG}

微生物起源トランスグルタミナーゼの原末（MTGと略 す）および製剤化した湎用のトランスグルタミナーゼ製剂 「アクティバ」TG-M コシキープ（TG-M と略す）を供試し た. MTG 原末の力価は 1000 ユニット/g，さらに，製剤化 した TG-M は 25 ユニット/gである。

\section{2. 原料小麦粉}

中華湎には準強力粉として日清製粉(株)の「特ナンバー ワン」（タンパク質 $11.2 \%$, 灰分 $0.34 \%$ ）を用いた。 かんす いは日本コロイド(株) の「かんすい A」を供試した。

\section{3. 副原料}

DMV ジャパン(社) のタンパク質部分分解物「グルタミ ンペプチド」（平均分子量約 3000）を供試した.

\section{4. 麺調製法}

(1) 生麺, 茹で湎

準強力粉 $1000 \mathrm{~g}$ に対して，市水 $360 \mathrm{~g}$ ，食塩 $10 \mathrm{~g}$ ，加 んすい A10 g, クチナシ色素 $1 \mathrm{~g}, \mathrm{TG}-\mathrm{M} の 0 〜 20 \mathrm{~g}$ を真空 ミキサー（(株)トーキョー麺機製 TVM03-0028 型) にて, $500 \mathrm{mmHg}$ の真空下で高速（95 rpm） で 4 分，低速（75 $\mathrm{rpm})$ で 3 分混捏した。これをロール式製麺機（(株)品川 製麺機製の 5WS-PSSB-8LP 型）を用いて製缅した後，麺 带を 2 枚あわせて, 複合を 1 回行った。ささらに, クリアラ ンス 1 回目 $3.4 \mathrm{~mm}, 2$ 回目 $2.8 \mathrm{~mm}, 3$ 回目 $2.3 \mathrm{~mm}, 4$ 回目 $1.4 \mathrm{~mm}, 5$ 回目 $1.25 \mathrm{~mm}$ として, 厷延を 5 回行い, $20^{\circ} \mathrm{C}$ に て 1 時間熟成した後に，切り刃\#22で切り出し「生麺」を 調製した.この生麺を 2.5 分間茹で処理して「茹で湎」を調 製した。 ゆで用水は $\mathrm{pH}$ 調整刜 (扶桑科学(株) 製の二ュー メンソルト）を $0.2 \%$ 添加し pH 5.5 にて茹で処理を行い, 茹で処理後, 直ちに, 物性および官能評価の試料として評 価並びに相関関係測定に供した。

(2) 酸処理麺, レトルト処理麺

調製した生麺を 1 分間茹で後, 直ちに水水 $\left(3 \sim 5^{\circ} \mathrm{C}\right)$ に て 30 秒間冷却して, $0.67 \%$ 乳酸溶液に 4 分浸漬処理して 「酸処理麺」を調製した。さらに，レトルト処理の方法は, (1)で調製した生麺を 1 分間茹で処理後, 冷却して 3 層の透 明レトルトパウチに充填し，日阪工業(株) 製の高温高圧槽 にて，熱水加熱方式で $121^{\circ} \mathrm{C}$ の熱水で中心が Fo 5.5 になる ように加熱殺菌処理を行い,「レトルト処理麺」として調製 した，酸処理麺およびレトルト処理麺は，常温で一昼夜保 管し，これらを翌日，注湯して 1 分後に評価用並びに相関 関係測定用に供した。

\section{5. 物性測定}

(1) 切断試験

切断試験の測定条件は, 茹で処理を 2.5 分行った茹で缅 を, 湯きりして 30 秒後に不動工業(株) のレオメー夕（型 式 2202 型）により，ロードセル $2 \mathrm{~kg}$, レンジ $200 \mathrm{~g}$, ピア ノ線プランジャーを用いてテスト速度 : $6 \mathrm{~cm} / \mathrm{min} の$ 条件 にて，物性を 2 分間で測定した．測定回数は 5 回行い，最 高値と最低值を除き残りの 3 回の測定の平均值とした。測 定項目はかたさの指標となる切断応力（g） と官能評価の コシの強さと相関の高い切断エネルギー值 $\left(\mathrm{erg} / \mathrm{cm}^{2}\right)$ を 測定した，茹で伸び抑制は，さらに，茹で湎を直ちに，スー プ中に浸した状態で 30 分間の経時変化を測定した。この 時のスープ温度はスタートが $93^{\circ} \mathrm{C}$ から 30 分後では $52.5^{\circ} \mathrm{C}$ まで低下した。

酸処理湎は発泡スチロール容器で注湯してから，1 分後

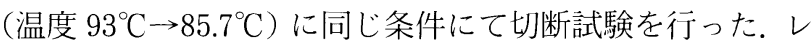
トルト処理麺は酸処理麺と同じように，注湯して 1 分後に 物性を測定した。

(2) クリープ試験

クリープ試験は山電(株) 製のレオナー（型式 RE-3305 型）を用い， $25^{\circ} \mathrm{C} \pm 1{ }^{\circ} \mathrm{C}$ の室温にて行った。喫食状態でカッ トした茹で麺および酸処理麺の応力と歪の間に線形性があ るとみなせる範囲で測定した。すなわち，応力 $20 \mathrm{~g}$ にて 1 分間荷重後， 1 分間 除重して得られたクリープ曲線を用 い粘弾性解析を行い，官能評価およびクリープ試験の各パ ラメーターとの相関関係をマッキントッシュの相関係数計 算式で算出した。

\section{6. 官能評価}

官能評価は，茹で麺，酸処理およびレトルト処理麺のい ずれも物性評価と同じく, 喫食状態になるように茹で処理 等を行い実施した。評価項目は弾力, 粘り, コシの強さの 3 項目に設定した。評価基準は, 各項目とも強いこと=好 ましい評価を判断基準として，評点基準は酸処理麺を 2 点 として，10段階評価法で評価した。 パネラーは湎評価専門 員 5〜10 名とした．事前に基準となる酸処理麺のかたさを パネル間で認識を統一し，試料毎に評点を評価シートに 沿って評価した。生湎の茹で処理および酸処理麺の官能評 価值と切断試験，クリープ試験の相関係数から最も適切な 評価項目を設定した。

\section{7. $\mathrm{pH}$ 測定}

麺線の $\mathrm{pH}$ は生麺 $40 \mathrm{~g}$ に純水 $120 \mathrm{ml}$ を加え, トリオブ レンダーにて $2000 \mathrm{rpm}$ で 3 分間ホモジナイズして測定し た。

\section{8. $\varepsilon$ - $(\gamma$-Glu) Lys 結合量測定}

$\mathrm{Folk}^{13)}$ らの方法に従って定量した. 試料を凍結乾燥後, プロテアーゼで分解し，アミノ酸と G-L 混合液を逆相カラ ムにより G-L を含む画分を分取し，この分取した G-L を o-phthaldehyde (OPA) で光誘導体化することによって 
定量し, 試料中の固形分 $100 \mathrm{~g}$ あたりの $\mu \mathrm{mol}$ で表した.

\section{実験結果および考察}

\section{1. 麺質と物性値の関係}

麺物性は微妙な粘り之弾力から構成されることから，官 能的な歯ごたえの評価が中心となってきた。一方では，コ シに対応する客観的なテクスチャ一評価も検討されている が十分とはいえない，そこで，切断試験，クリープ試験か ら得られたパラメータと官能評価の結果との関係を検討 し, 喫食状態での中華麺の各パラメー夕の相関をみた結果 を表 1 に示した。クリープ試験による粘性率が，官能的評 価による弾力およびコシと高い相関関係をもち, その相関 係数は弾力に対して 0.953, コシに対して 0.915 之高く, 両 者間ではいずれ屯危険率 $1 \%$ 以下で有意性がみられた。 ま た, 粘り之粘性率の間む 0.891 と他の客観的パラメー夕値 よりも相関が高く, 両者間でも危険率 $1 \%$ 以下で有意性が みられた. 切断試験による切断エネルギーも弾力, コシ, 粘り上高い相関を示し，その相関係数は弾力に対して

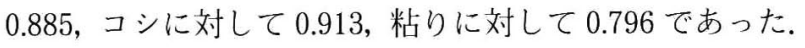
これらの関係に扔いて，切断エネルギーと弾力やコシの間 では危険率 $1 \%$ 以下，粘りとの間では危険率 $5 \%$ 以下で有 意性がみられた。 すなわち，切断試験では切断強度よりむ 切断エネルギーの方が官能的食感と高い相関をむった。 よって，麺のコシは粘性率および切断エネルギーと，粘り は粘性率抢よび切断エネルギーと高い相関をもつことが確 認された．以上より，兡物性の客観的パラメータとして粘 性率と切断エネルギーとした。 また, 酸処理湎の切断試験 およびクリープ試験から得られたパラメー夕の相関をみた 結果, 表 2 に示すように, 官能評価のコシに対して, 切断

\section{表 1 中華麺における特性值間の相関係数}

\begin{tabular}{|c|c|c|c|c|c|}
\hline & $\begin{array}{c}\text { 切断強度 } \\
(\mathrm{g})\end{array}$ & $\begin{array}{c}\text { 切断エネルギー } \\
\left(\mathrm{erg} / \mathrm{cm}^{2}\right)\end{array}$ & $\begin{array}{c}\text { 弾性率 } \\
\text { (Eo) }\end{array}$ & $\begin{array}{c}\text { 遅延時間 } \\
\left(J_{1}\right)\end{array}$ & $\begin{array}{c}\text { 粘性率 } \\
(\eta \mathrm{N})\end{array}$ \\
\hline 弾力 & $0.887^{\circ}$ & $0.885^{\star *}$ & 0.237 & 0.62 & $0.953 \%$ \\
\hline 粘り & 0.764 & $0.796^{*}$ & 0.057 & 0.562 & $0.891 \%$ \\
\hline コシ & $0.869 \%$ & $0.913 \%$ & 0.153 & 0.667 & $0.915^{* *}$ \\
\hline
\end{tabular}

危険率 $5 \%$ 的危険率 1\%以下

茹で中華缅; 切り出し \#22 角, 茹で処理 2.5 分

表 2 酸処理中華麺における特性值間の相関係数

\begin{tabular}{|c|c|c|c|c|c|}
\hline & $\begin{array}{c}\text { 切断強度 } \\
\text { (g) }\end{array}$ & $\begin{array}{c}\text { 切断エネルギー } \\
\left(\mathrm{erg} / \mathrm{cm}^{2}\right)\end{array}$ & $\begin{array}{l}\text { 弾性率 } \\
\text { (Eo) }\end{array}$ & $\begin{array}{c}\text { 遅延時間 } \\
\left(\mathrm{J}_{1}\right)\end{array}$ & $\begin{array}{c}\text { 粘性率 } \\
(\eta \mathrm{N})\end{array}$ \\
\hline 弾力 & $0.791^{*}$ & $0.790^{\circ}$ & 0.441 & 0.185 & 0.705 \\
\hline 粘り & $0.857 \%$ & $0.857 \div$ & 0.532 & 0.135 & 0.688 \\
\hline コシ & $0.827 \%$ & $0.828 \%$ & 0.492 & 0.098 & 0.664 \\
\hline
\end{tabular}

危険率 $5 \%$ 新危険率 $1 \%$ 以下

酸処理麺; \#22 切り出し生中華麺を 1 分茹で後 $0.67 \%$ 乳酸溶液 4 分浸漬した酸処理麺を注湯して 1 分後に測定 (pH3.98)
エネルギーは 0.828 , 切断強度に対して 0.827 の相関が得ら れ, 粘りに対しては切断エネルギー, 切断強度が, それ ぞれ 0.827, 0.857 之高い相関がともに得られた。

\section{2. 各種麺物性に及ぼす MTG の影響}

中華麺に扔ける切断エネルギーに及ぼす影響をみた結 果, 図1のように, MTG の添加量の増大に伴って, 切断エ ネルギー值か增加した．また，粘性率む増加することから 粘り屯向上することが示された．切断エネルギー之粘性率 の両者の増加は, 中華缅における各評価項目ごとのプロ ファイル評価では, 好ましい湎物性が得られるというこ上 が示された。

中華麺はかんすい添加により, 麺の $\mathrm{pH}$ が 10〜11 之高 い. MTG の至適 $\mathrm{pH}$ は 5 9 9ので中華麺中での反応性が 課題であった。 そこで，高 $\mathrm{pH}$ 下での MTGの作用低下を ふせぐために，かんすいの添加量を低減することを検討し た．図 2 では $40 \%$ 加水の中華麺において，かんすい量を $1 / 3$ まで減じ, その結果, pH 11.0 を 8.5 まで低下した場合, MTG の反応性が増加し, 切断エネルギー值が $\mathrm{pH} 11 /$ かん すい $1 \% / \mathrm{TG}-\mathrm{M} 1 \%$ 区より高くなった。この結果, MTGに はかんすいを代替する機能があることが示唆された。

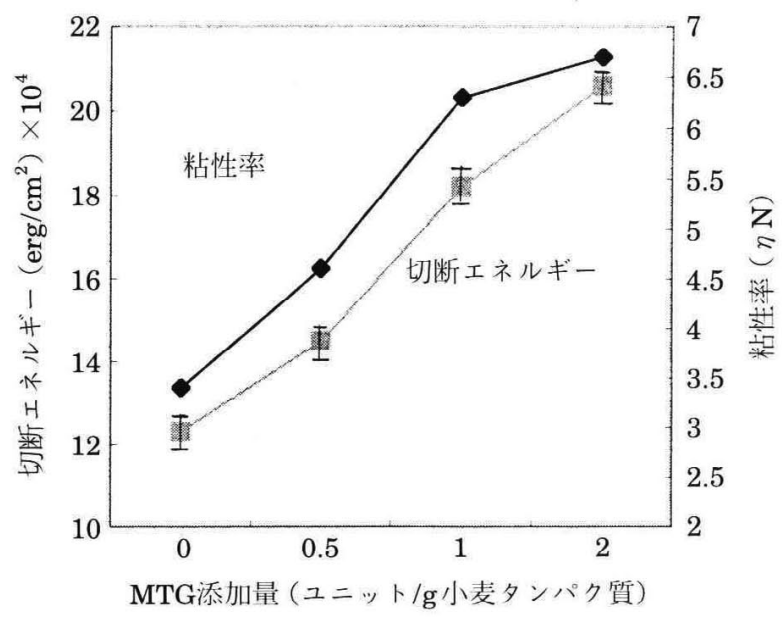

図 1 茹で中華缅の切断エネルギー, 粘性率に及ぼす MTG の影響 切り出し\#22 角, 茹で 2.5 分

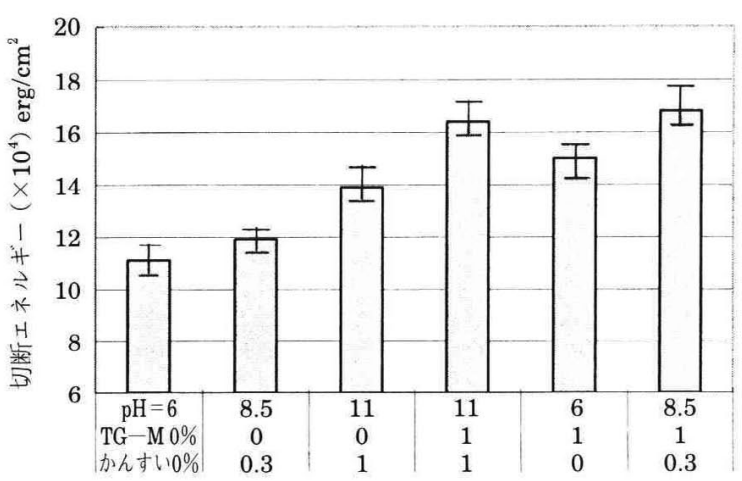

図 2 中華麺における切断エネルギーに及ぼす $\mathrm{pH}$ の影響 切り出し \#22 角, 茹で 2.5 分 


\section{G-L 結合生成量と物性の関係}

MTGの小麦タンパク質への作用性を検討することを目 的として，うどん，中華湎に対する小麦タンパク質 $1 \mathrm{~g}$ あ たりの MTG 添加量と G-L 生成量の関係を図 3 に示した. この結果, うどん, 中華麺, いずれにおいても MTG 添加 量の増加に伴って G-L 生成量が増加した. MTG 添加量 に対する小麦粉 $1 \mathrm{~g}$ あたりの G-L 生成量について, 中華麺 ではうどんの約 $1 / 3$ であった。このことは, 中華麺に用い られるかんすいの添加によって, 中華麺の $\mathrm{pH}$ が 10.5 11.0 という高 $\mathrm{pH}$ になるとにより, MTGの小麦タンパ ク質への反応性が低下したためと考えられた。

\section{4. 麺物性に及ぼすタンパク質部分分解物の影響}

MTG の麺物性への影響は, MTG 単独系では, 官能評価 では, MTG 量の増加にしたがって, 粘りよりも弾力が際 だって高くなるために，ボキボキした食感になる傾向がみ られた，そこで, MTGとの併用において, 湎物性の改質を

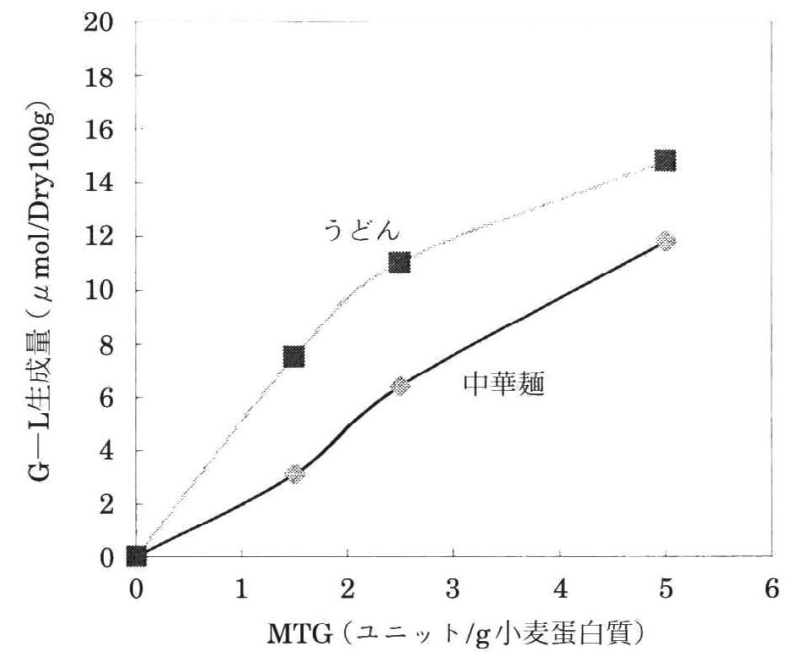

図 3 中華麺, うどんにおける GL 生成量に及ぼす MTG の影響 中華麺; 切り出し \#22 角, 茹で 2.5 分 うどん; 切り出し \#12 角, 茹で 15 分

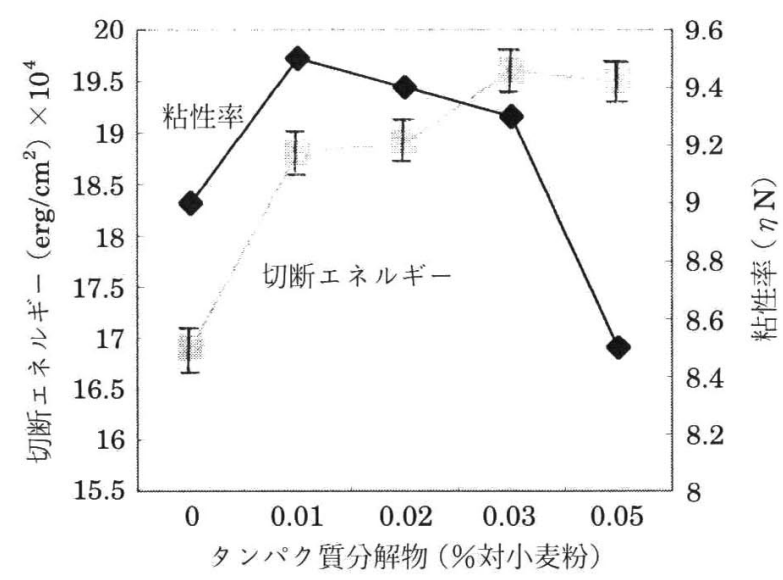

図 4 中華麺におけるタンパク質加水分解物の切断エネルギー, 粘性率に及ぼす影響

加水 $40 \%$, 食塩 $1 \%$, 加すい $1 \%$ MTG 添扣量 : 2.5 ユニット/小麦蛋白 $1 \mathrm{~g}$
さらに高め, 粘弾性のある中華麺の物性を得るために, 図 4 に示すように, タンパク質部分分解物との併用効果を検 討した. MTGとタンパク質分解物の併用の結果, MTGの 単独の場合より，MTGとタンパク質分解物との併用に よって, 中華麺の弾力と粘りのバランスのとれた, 中華麺 のコシの強さが増す傾向を示した. タンパク質部分分解物 の添加量が $0.015 \%$ の低添加量の併用において，官能的に あ弾力が強く，噛みごたえ感のあるもちっとした好ましい 食感の中華缅の物性を得ることができた.

\section{5. 耐酸性, 耐レトルト性の付与}

中華湎の酸処理およびレトルト処理の麺物性の与える影 響について図 5,6 に示した. 中華麺での酸処理した場合に 掞いては, TG-M 処理によって, 切断エネルギー值とコシ の強さが増加した. 図6においても酸処理麺と同様に TG-M の添加量の増加によって, 切断エネルギー值とコシ の強さが増す傾向がみられ, 特に, 酸処理缅に比べて, レ トルト処理麺の方が効果がみられた。これは, 酸処理によ る浸漬時間での水分含量の影響もみられるものと推察され

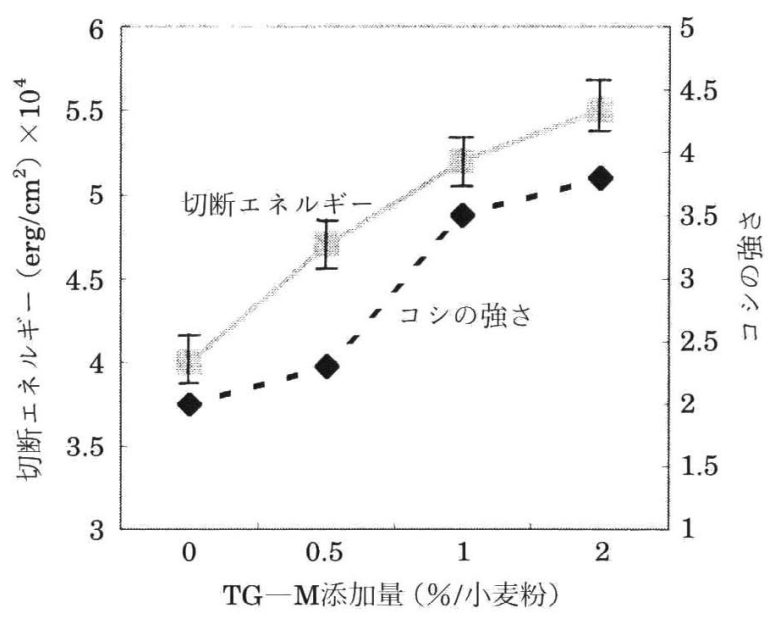

図 5 酸処理中華麺の物性に及ぼす TG-M の影響 茹で 1 分後, $0.67 \%$ 乳酸溶液に 4 分浸漬, $\mathrm{pH} 3.98$

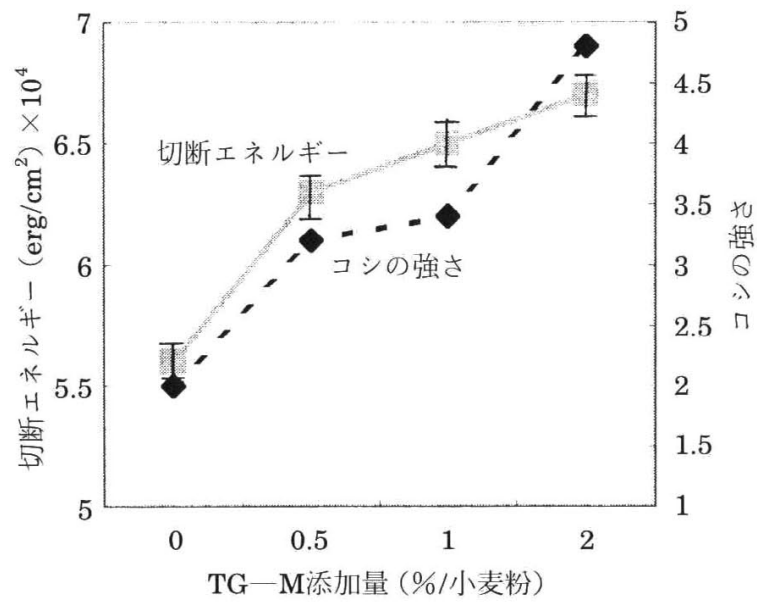

図 6 レトルト処理中華麺の物性に及ぼす TG-M の影響 茹で 1 分, レトルト処理 $121^{\circ} \mathrm{C} 6.5$ 分加熱: Fo 5.5 
た.

\section{6. 茹で伸び抑制効果}

中華麺に抢けるゆで伸び抑制機能をみた結果を困 7 に示 した. 製逎後，\#22 の切り刃により切り出した生麺を茹で 処理 2.5 分行い, $93^{\circ} \mathrm{C}$ のスープ中での物性の経時变化をみ た。この時のスープは 30 分経過で $53^{\circ} \mathrm{C}$ まで低下した状態 で測定した。 その結果, 無添加品に対して TG-M 量の増加 に伴って，スープ中での麺線のゆで伸び抑制効果が得られ た，湎の改質剤として用いられる素材は，呈味性に影響す るものが多くみられるが, 本酵素は無味, 無臭ゆえに, 麺 の味には影響を与えることなく, 麺物性の改質が可能と なった。

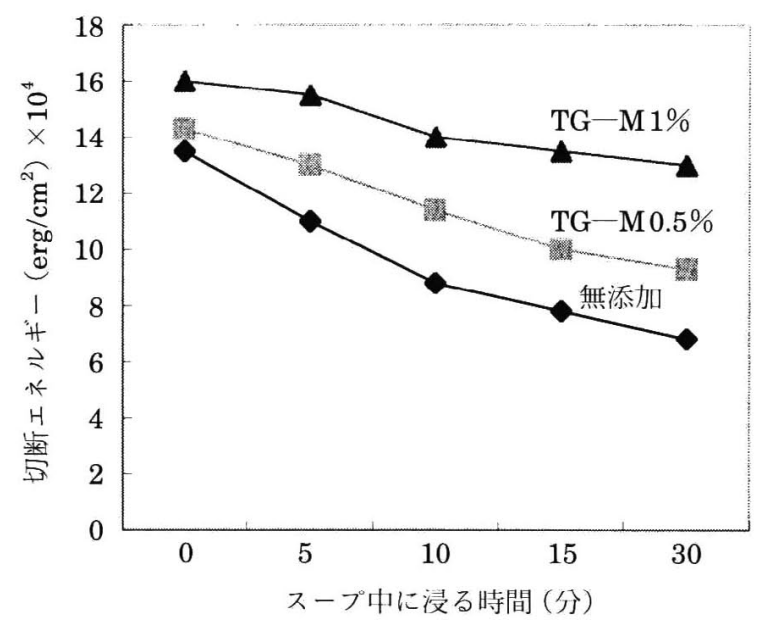

図 7 中華麺のスープ中での茹で伸び抑制

归 $36 \%$, 食塩 $1 \%$ ， かんすい $1 \%$ ゆで 2.5 分

\section{要}

\section{約}

中華湎において MTG および TG-M の添加による麺物 性改善, 茹で処理および酸処理, レトルト処理における麺 物性改質の機能を明らかにした。この小麦タンパク質の改
質は, 物性や味の点から従来みられない効果を示すもので あった，この改質は酵素作用によって G-L 結合が形成され るためであり, 麺に求められる弾力と粘りのバランスのと れた好ましい食感をもつ麺物性に改質された。さらに，ゆ で処理後の麺物性の経時的抑制効果も発現することが可能 となった，麺物性にとって重要となる，コシの強さおよび 粘りは粘性率と切断エネルギー值と高い相関を示した。

\section{文献}

1）柴田茂久, めん類の物性と品質について,「食品と物性」, 第 6 集 (食品資材研究会)，169-182（1979）。

2）三木英三，製造条件がめんのテクチャーに及ぼす影響，食 品之科学, 10, 79-83 (1999).

3）多田正敏, 讃岐うどんの物性,「食品之物性」, 第 7 集（食品 資材研究会)，161-168（1981）。

4）柴田茂久, 畐の食味と科学, 食品之科学, 7. 80-89 (1984).

5）安永 隆，小麦粉の製め九適性， 口食丁誌，13，148-157 (1966).

6）柴田茂久, 今井 徹, 豊島英親, 梅田寺司, 石田紀男, 照射 小麦の製めん適性，日食工誌，21，161-167（1974）.

7) Shimizu, T., Fukawa, H. and Ichiba, A., Physical Properties of Noodle. Cereal Chem., 35, 34-46 (1958).

8）渡辺幸夫，永沢 信，応力緩和測定によるメンの粘弾性の 検討, 口食丁誌, 15，466-468（1968）。

9) H. Ando, M. Umeda, A. Matsuura, M. Nonaka, R. Uchio, H. Tanaka and M. Motoki, Purification and Characteristics of a Novel Transglutaminase Derived from Microorganisms, Agric. Biol. Chem, 53, 2613-2617 (1989).

10）添田孝彦, 山㠃勝利, 坂口正二, 食品用酵素製剂の食肉加上 への利用，食品之科学，8，95-100（1993）。

11）添田孝彦, 須佐康之, 山㠃勝利, 渡井山清一郎, 坂儿正， 酵素製剤による畜肉・水産練り製品の品質改良, ジャバン フードサイエンス，8，50-56 (1993).

12）添田孝彦, 石井智穂, 山㠃勝利, 村瀬和良, 豆腐物性に及ほ すトランスグルタミナーゼの影響，食科工，42，4，254-261 (1995).

13) Folk J. E. and Chung S.I., Molecular and Catalytic Properties of Transglutaminases, Adv. Enzymol. 38, 110171 (1973).

(平成 15 年 5 月 22 日受付, 半成 15 年 10 月 14 日受理) 